\section{War and the Austrian School: Ludwig von Mises and Friedrich von Hayek}

\section{Christopher Westley, William L. Anderson, and Scott A. Kjar}

$\mathrm{T}$ understand the thoughts of Ludwig von Mises and Friedrich von Hayek on war, it is necessary to understand their fundamental views on economics. Like their Austrian School predecessors_-Carl Menger, Eugen von Böhm-Bawerk, and Friedrich von Wieser-von Mises and von Hayek believed that a free economy was the natural outgrowth of a free society. Free men voluntarily transact with each other in free markets, and society itself is an outgrowth of these voluntary transactions. ${ }^{1}$ Further, free markets serve as a method of allocating society's scarce resources: In particular, prices serve to highlight consumer desires, and entrepreneurs are guided to business decisions that support consumer preferences.

War necessarily violates the market by overriding consumer preferences in favor of the preferences of governments and their militaries. Likewise, prices as a guide to resource allocation are distorted by wartime edicts including price controls, quotas, and outright confiscation. It is on these foundation that Mises's and Hayek's views on war are to be understood. ${ }^{2}$

The early professional years of Ludwig von Mises

Although Mises wrote his best-known works after he came to the United States as a refugee from world war II and the Nazi onslaught, even his pre-world war I writings demonstrate his commitment to classic liberalism and free markets. In his first major work, The Theory of Money and Credit (1912), Mises argues that free markets and an honest monetary system based on gold would preserve social harmony. Later, in Omnipotent Government (1944a), Mises argues that the wave of protectionism proceeding the outbreak of world war II only heightened the prospects of international conflict, while the liberal (free market-free trade) economies would help preserve peace.

When world war I broke out in 1914, Mises served in the Imperial and Royal Army of Austria-Hungary. Badly injured, he was given a position on the Scientific Committee for War Economics, part of the War Ministry. His pro-market, hence not pro-war, views made him unpopular with other members of the Committee. According to Hülsmann, Mises was a dissenting voice "on the prospective economic benefits of military victory. He definitely did not believe that conquests in the East would convey any economic advantages for the future Austro-Hungarian economy.”3

Following the war's end, which split the former empire of Austria-Hungary into two small countries, Mises wrote Nation, State, and Economy (1919) in which he addressed economic issues of war. Prophetically, he warns against a government policy of revenge:

"To retaliate for wrong suffered, to take revenge and to punish, does satisfy lower instincts, but in politics the avenger harms himself no less than the enemy. The world community of labor is based on the reciprocal advantage of all participants. Whoever wants to maintain and extend it must renounce all resentment in advance. What would he gain from quenching his thirst for revenge at the cost of his own welfare?” [p. 181]

Mises roundly criticizes war socialism — defined as increased state control of the economy during wartime-in Germany and Austria, claiming that it hastened their final collapse. In both countries, socialists and democrats rushed to fill the void left by the destruction of the monarchy, but neither group held to the classic liberalism that had dominated European political thought for a century.

In 1920, Mises wrote an essay, "Economic Calculation in the Socialist Commonwealth,” in which he laid out a critique of socialism based on his belief that a pure socialist economy could not exist. Expanded to book length in Socialism (1922), Mises portrays world war I as total war-a war that required the complete mobilization of people and resources. ${ }^{4}$ To Mises, war combined all of the illiberal things he most despised, the marshaling of resources along with the activities of once-free individuals to satisfy a "national purpose." Contrary to beliefs of Marxists, Mises did not believe that capitalism had internal contradictions that required periodic wars in order to keep from spiraling into recessions. Rather, Mises believed that periodic wars were themselves contradictions to capitalism and classic liberalism.

\section{Mises, war, and socialist calculation}

The key to Mises's views on war and socialist calculation are found in his criticism of central allocation of goods and government control of methods of production. In "Economic Calculation in the Socialist Commonwealth," Mises made an important point about the role prices play in resource allocation, and especially in allocating factors of production. For him, prices of final goods are determined by the interplay of suppliers and demanders in the market, and, following Menger, the prices of these 
final goods in turn are imputed to their higher-order factors of production. The value of the factors of production used for any class of goods, such as war goods, is compared with the value of those same factors used in the production of other goods. This allows resource owners to better select how to allocate scarce resources among competing products, and allows entrepreneurs to select production methods among alternate allocations of capital, labor, natural resources, and time.

Mises did not specifically address war socialism in his 1920 essay, but neither did he make an exception for it. He believed that government demands upon individuals to carry out a "national purpose" were abhorrent, something he addressed in later writings. For Mises, war socialism was not a way to rationally direct war production, which is how its supporters justified it. Instead, he believed that total wars such as the two world wars empower the state in a way that enable it to enforce wartime production rules. ${ }^{5}$

Mises held this position even when he emphasized the need for Hitler and the Nazis to be defeated. For example, in Omnipotent Government: The Rise of the Total State and Total War (1944a), Mises wrote that the Nazi regime sought "world hegemony” in order to enjoy a higher standard of living through conquest:

“The essential point in the plans of the German National Socialist Workers' party is the conquest of Lebensraum for the Germans, i.e., a territory so large and rich in natural resources that they could live in economic self-sufficiency at a standard not lower than that of any other nation. It is obvious that this program, which challenges and threatens all other nations, cannot be realized except through the establishment of German world hegemony.” [p. 1]

Mises further emphasized that war and conquest are not in fact necessary for a higher standard of living. A simpler and better way is to practice free trade and have free institutions:

"Within a world of free trade and democracy there are no incentives for war and conquest. In such a world it is of no concern whether a nation's sovereignty stretches over a larger or a smaller territory. Its citizens cannot derive any advantage from the annexation of a province. Thus, territorial problems can be treated without bias and passion; it is not painful to be fair to other people's claims for self-determination.” [p. 3]

Mises believed he was standing against totalitarianism and believed that war-and especially the total wars of the 20th century-empowered the state and collectivism. His warnings came during the 1920s and 1930s when collectivist ideals grew in Europe, becoming fascism in Italy and Germany and communism in the Soviet Union.

As an anti-collectivist Jewish intellectual, Mises knew he was not safe in Vienna and so, in 1934, he and his wife moved to Geneva, in neutral Switzerland. In 1940, as Germans marched across France and the Low Countries, the von Mises's fled for the United States, arriving in a country that was soon to go to war as well.

Writing Omnipotent Government (1944a) and Bureaucracy (1944b) during the world war II years, the former identifies National Socialism as a form of collectivism not unlike the socialism of the U.S.S.R. Mises declares that modern wars are not the result of "unfettered" capitalism but rather of economic nationalism, promoted both by autocratic and democratic governments:

"The fateful error that frustrated all the endeavors to safeguard peace was precisely that people did not grasp the fact that only within a world of pure, perfect, and unhampered capitalism are there no incentives for aggression and conquest. President Wilson was guided by the idea that only autocratic governments are warlike, while democracies cannot derive any profit from conquest and therefore cling to peace. What President Wilson and the other founders of the League of Nations did not see was that this is valid only within a system of private ownership of the means of production, free enterprise, and unhampered market economy.” [pp. 4-5]

In Bureaucracy, Mises argues that government cannot effectively run an economy in the same way as would be done in a free-market system. He blames world war II and all of the resulting economic dislocation on the growing power of the state:

"Economic interventionism is a self-defeating policy. The individual measures that it applies do not achieve the results sought. They bring about a state of affairs, which-from the viewpoint of its advocates themselves-is much more undesirable than the previous state they intended to alter. Unemployment of a great part of those ready to earn wages, prolonged year after year, monopoly, economic crisis, general restriction of the productivity of economic effort, economic nationalism, and war are the inescapable consequences of government interference with business as recommended by the supporters of the third solution. All those evils for which the socialists blame capitalism are precisely the product of this unfortunate, allegedly 'progressive' policy. The catastrophic events which are grist for the mills of the radical socialists are the outcome of the ideas of those who say: 'I am not against capitalism, but ...' Such people are virtually nothing but pacemakers of socialization and thorough bureaucratization. Their ignorance begets disaster.” [p. 119]

In 1949, Mises published his most important work, Human Action. This includes a chapter titled "The Economics of War." In it he again stresses that free markets are based on peaceful cooperation and how this cooperation falls apart when "citizens turn into warriors” (p. 821). One virtue of the combined idea of limited war and free markets was the recognition that free trade was a necessary prerequisite for peace 
because it makes little sense for a country to wage war against its trading partners. In the absence of free trade, conflicts over territory, religion, ideology, culture, and a host of other issues fester with no countervailing reason for calmness or rationality among the belligerents. While a nation might not wish to engage in war with its trading partners, it has no such constraints concerning those with whom it does not trade. As such, many conflicts cannot be fixed by creating new bureaucracies (such the League of Nations or the United Nations) because the participants in war have no reason to stop (p. 821).

War reduces the international division of labor because it reduces opportunities to engage in trade. Mises argues that if the tailor goes to war against the baker, then he must bake his own bread. What is more, if the tailor does this, he will soon be in worse shape than the baker. This was one of the reasons why, Mises wrote, the South lost the American civil war, and why Germany lost both world wars. These problems arise because of the existence of what Mises calls the "inter-regional division of labor" (p. 829).

Finally, Mises writes that it is humans' ability to cooperate that separates them from other animals. To cooperate, they first must overcome innate tendencies for aggression, and in so doing they become better off because they extend the division of labor. "Interventionism generates economic nationalism, and economic nationalism generates bellicosity. If men and commodities are prevented from crossing the borderlines, why should not armies try to pave the way for them?” (p. 832). Mises laments how far we have come from the era of limited war. In the 1940s, 50 million were killed in war, reflecting what Mises calls the spirit of conquest that, if not countered, will result in the destruction of civilization. ${ }^{6}$ Mises concludes that the ideologies that generate war-collectivism and statism-must be discarded and replaced with the ideologies of freedom and free markets:

"The market economy involves peaceful cooperation. It bursts asunder when the citizens turn into warriors and, instead of exchanging commodities and services, fight one another.” [p. 817]

The early years of Friedrich von Hayek

Like Mises, Hayek is in many ways a product of his lineage, both intellectually and biologically. His family was involved in medicine and biology, and young Friedrich was encouraged to study these disciplines. Indeed, Hayek worked for a time in the Institute of Brain Anatomy. This would help pave the way for such works as The Sensory Order (1952). At the University of Vienna, Hayek took doctorates in both law and political science. (The Faculty of Economics was located in the school of law.) There, Hayek became a devotee of his teacher, Friedrich von Wieser, and was strongly influenced by the work of Carl Menger. After graduation, upon Wieser's recommendation, Hayek went to work for Mises in the Austrian government. The pair would continue their collaboration at the Austrian Institute for Business Cycle Research. Works that developed from this time in Hayek's career include Monetary Theory and the Trade Cycle, and Prices and Production.

In 1931, Hayek was persuaded to join the London School of Economics (LSE). This was at the behest of Lionel Robbins (who, incidentally, eventually examined the topic of economics and war himself in The Economic Problem in Peace and War, 1947). At the LSE, Hayek both influenced and was influenced by Karl Popper. Hayek was also an early reader of Wittgenstein's works. Philosophy and the history of science became important elements in Hayek's work. Also at LSE, Hayek famously exchanged letters with Keynes. Some of the ideas developed during this time would later appear as his primary thesis in The Fatal Conceit (1988). One of the keys to his thought is the idea of a spontaneous order, or a cultural order that develops from the voluntary interactions of society's participants, rather than from the planned structure imposed by government or other authoritative force. We see that both the influences on Hayek and those whom Hayek influenced in turn as being broad and diverse. To understand and apply Hayek's thought to war, we need to view him not only as an economist but as a broad social thinker with influences in philosophy, psychology, the history of science, political science, and culture.

\section{Hayek on war}

We trace Hayek's views on war through several key writings, starting with "Socialist Calculation” (1935). Writing the introduction to a book on the socialist calculation problem, which included an older essay by Mises, Hayek lays out what he considers as the great and insurmountable problem of socialism: Even if a planner knows what needs to be produced, how does he know how to allocate the necessary resources to produce the goods? Since there are many factors of production that can be applied to many different final goods, and many different ways to produce each good, the allocation problem is not merely of what to produce, but of how to produce it, as well as what not to produce. Absent prices, the opportunity cost of the foregone allocation cannot be understood.

In subsequent articles, Hayek grapples with Britain's problem with Germany: Given that war seemed inevitable, how was Britain to devise plans that allocate resources for the war effort while minimizing any attendant economic disruption? More bluntly, how does Britain mobilize for war against Germany without turning its economy into a reflection of the German economy? For Hayek realized that many of his intellectual opponents saw the impending war with Germany as an opportunity to grow the state in ways that were not possible during peacetime. In this, Hayek would develop a theme taken up by Robert Higgs (1987): the "ratchet effect” of government expansion. Hayek saw that once planners expanded their hold on an economy, they would not want to let go.

In “Prices versus Rationing” (1939a), Hayek recognizes that the military will need 
to extract resources from the economy first. Prior extraction, however, does not mean that rationing, quotas, or other perturbations of the market are necessary. Instead, Hayek says, during war, allow the military to extract what it needs and leave the free market to sort out the rest. The market will equilibrate the remaining supply with the civilian demand for increasingly scarce resources, and entrepreneurs will be motivated to provide additional goods in precisely those areas where scarcity is deemed most urgent by the populace, as evidenced by corresponding price changes. Any political effort to fix prices or to establish quotas, he pointed out, will serve merely to cause inefficient allocation of resources during the very period in which they are the most scarce. If prices cannot rise, then they lose their signaling power to entrepreneurs and investors. The result is waste, which reduces the current as well as the future civilian standard of living, and also reduces the very availability of resources upon which the military might need to draw later.

“The Economy of Capital” (1939b) follows the same logic, but applied to financial markets. A key element in Austrian theory-from Menger and Böhm-Bawerk to Mises and Hayek and then to Garrison and the modern Austrians-is that interest rates are the intertemporal price of capital goods. High interest rates generate more saving and the reduction of current consumption, but discourage capital formation and what Böhm-Bawerk called “roundabout” methods of production since only highly profitable projects can cover the interest expense over a long time period. Low interest rates generate more desire by entrepreneurs to engage in capital-intensive long-term projects and more roundabout production, but discourage consumers from reducing current consumption and freeing up scarce resources. A free market equilibrates the interest rate according to society's time preference rate, thereby generating the mix of consumption goods and capital goods desired by the society.

Government interventions that influence or set interest rates, Hayek noted, lead to swings in capital allocation, and often generate business cycles. This idea, which Hayek expressed in several writings, was one of the keys to his Nobel Prize award, with the committee citing Hayek, along with Gunnar Myrdal, “for their pioneering work in the theory of money and economic fluctuations and for their penetrating analysis of the interdependence of economic, social, and institutional phenomena."”

As in the goods market, Hayek recognized that the military might have a prior claim on capital, but once the military has established that claim, the remainder should be left to the market. Any government interest-rate fixing will merely generate the sort of malallocation of capital that would hinder not only civilian production during and after war, but could also hinder later military production both during and after war, a state of affairs that could actually cause a nation's military defeat. Thus, Hayek argued, economic central planning during war is, if anything, even more self-defeating than economic central planning during peace.

Hayek's “The Economics of Planning” (1941) reiterates the argument concerning the complexity of the economy and the impossibility of any planner being able to manage the huge amounts of information necessary to allocate resources. In contrast,
Hayek points out, an entrepreneur does not need to plan for an entire economy. He needs only to see a few prices around him, prices of potential competitors, prices of factors of production, and prices that his own services can command in other employ. In this way, he coordinates with other entrepreneurs in choosing how scarce resources will be allocated, since they will be allocated to that entrepreneur who values them the most, as evidenced by his willingness and ability to pay higher money prices for them. Another point Hayek raises concerns the amount of central planning that occurs during wartime as compared to peacetime. He notes that there is no deficiency in the free market that necessitates increased planning. Rather, the deficiency lies in political leadership and in the insufficient understanding of the workings of the economy. As such, politicians make bad decisions that throw markets into chaos, and then propose planning as a solution, rather than allowing the market to arrive at its own resource allocation.

In his most famous work, The Road to Serfdom (1944), Hayek writes that planning is "the deliberate organization of the labors of society for a definite social goal" (p. 56). However, in democracy no single social goal exists:

"And we all think that our personal order of values is not merely personal but that in a free discussion among rational people we would convince the others that ours is the right one. The lover of the countryside who wants above all that its traditional appearance should be preserved and that the blots already made by industry on its fair face should be removed, no less than the health enthusiast who wants all the picturesque but unsanitary old cottages cleared away, or the motorist who wishes the country cut up by big motor roads, the efficiency fanatic who desires the maximum of specialization and mechanization no less than the idealist who for the development of personality wants to preserve as many independent craftsmen as possible, all know that their aim can be fully achieved only by planning — and they all want planning for that reason.” [pp. 54-55]

It matters not that the planner is some sort of specialist with a greater or different education. It makes no difference that the planner has at his grasp reams of statistics and data that an ordinary person does not have. The fact is that all central planning requires a decision by the planner as to which goal is best and then which plan is best to achieve that goal. The key Hayekian objection is that because no central planner can possess all of the disparate pieces of knowledge found in society, no central planner can allocate resources as efficiently as can the decentralized market. Since war is coordinated by central planners, it necessarily follows that war planners will generate resource misallocations and cause widespread inefficiencies in production. Once these occur, they will have ongoing effects not only during war but also thereafter since war allocation alters the very structure of capital in an economy. For this reason, Hayek says, any planning that goes on-because of the nature of military needs, not because of the nature of the economic structure-must be temporary, 
abandoned the instant an armistice is signed. Leaving any vestige of war planning in place after war leads to Higgs's ratchet effect, and to what Hayek feared would be a Road to Serfdom in which much of the economy would be subservient to the demands of government planners, both military and civilian.

\section{Conclusion}

By questioning the state as a force of social good, the writings of Mises and Hayek on economics and war went against the intellectual tide of their day. Free markets, and especially free trade, were not the causes of war; indeed, these served as bulwarks for peaceful international relations. Mises especially saw socialism and statism as evils that set people against one another, and he believed that "national purpose," emphasized by collectivist states, led to conflict and war. Hayek believed that planning led to serious economic resource misallocation, both in the present and in the future, leading people down a road to serfdom.

Neither Mises nor Hayek were pacifists, nor were they opposed to war on the basis of principle. However, both men saw that the social, political, and economic developments that accompanied the total wars of the twentieth century posed a danger to the liberal order that they supported. Mises, in particular, was outspoken on this subject and despaired of what he saw, especially in the post-world war I fall of what had been old Europe, writing that "From time to time I entertained the hope that my writings would bear practical fruit and point policy in the right direction ... I set out to be a reformer, but only became the historian of decline." 8

For Mises, it was not just a case of opposing a particular war. Instead, he saw modern warfare as the antithesis of civilization: "What the incompatibility of war and capitalism really means is that war and high civilization are incompatible” (1949, p. 828). In Socialism (1922) Mises pursues the theme that private enterprise and economic exchange promote peace, while war promotes destruction:

"Society has arisen out of the works of peace; the essence of society is peacemaking. Peace and not war is the father of all things. Only economic action has created the wealth around us; labor, not the profession of arms, brings happiness. Peace builds, war destroys.” [p. 59]

Far from holding a “military Keynesianism” view according to which war is good because it promotes aggregate demand, Mises believed that economic disruption created by war destroys the liberal civilizations that had characterized Europe and the United States during the 1800s, and whatever the outcome of those wars, the legacy of government economic planning created lasting harm:

"Modern war is merciless, it does not spare pregnant women or infants; it is indiscriminate killing and destroying ... Nobody can foretell what will happen in the next chapter of this endless struggle. But this will not alter things, it will merely prolong for a short time the process of the complete destruction of civilization.” [1949, p. 832]

Notes

Christopher Westley, Department of Economics, Jacksonville State University, Jacksonville, AL, USA, may be reached at cwestley@jsu.edu. William L. Anderson, the corresponding author, is at the Department of Economics, Frostburg State University, Frostburg, MD, USA, and may be reached at banderson@frostburg.edu. Scott A. Kjar, Department of Economics, Labovitz School of Business and Economics, University of Minnesota Duluth, Duluth, MN, USA, may be reached at scottakjar@yahoo.com.

1. On the Austrian School founders, see Kjar and Anderson (2009).

2. The correct German names are, of course, von Mises and von Hayek. English usage has reduced this simply to Mises and Hayek, and this convention is followed in the remainder of the article.

3. Hülsmann (2007, pp. 274-275).

4. Also see Mises (1944a), Southerland (1998), and Bell (2007).

5. Hülsmann (2007).

6. 50 million: Denson (1999, p. xvii).

7. See http://nobelprize.org/nobel_prizes/economics/laureates /1974/hayek.html.

8. Quoted in J. Tucker, “Ludwig von Mises’s Memoirs.” http://www.lewrockwell. com/tucker/tucker156.html [accessed 24 December 2010].

\section{References}

Bell, D.A. 2007. The First Total War. New York: Houghton Mifflin Company. Brutzkuz, B. 1935. Economic Planning in Russia. London: Routledge and Sons. Coen, D.R. 2007. Vienna in the Age of Uncertainty. Chicago, IL: The University of Chicago Press.

Denson, J.V. 1999. The Costs of War. New Brunswick, N.J.: Transaction Publishers. Grassl, W. and B.Smith, eds. 1986. Austrian Economics: Historical and Philosophical Background. New York: New York University Press. 
Hayek, F.A. 1935 [1975]. “Socialist Calculation,” in F.A. Hayek, ed., Collectivist Economic Planning. New York: Augustus M. Kelly.

Hayek, F.A. 1939a. "Prices versus Rationing.” The Banker. Vol. 51 (September).

Hayek, F.A. 1939b. “The Economy of Capital.” The Banker. Vol. 52 (October).

Hayek, F.A. 1941. “The Economics of Planning.” The Liberal Review. Vol. 1, pp. 1-5.

Hayek, F.A. 1944. The Road to Serfdom. London: Routledge.

Hayek, F.A. 1945. “The Use of Knowledge in Society.” American Economic Review. Vol. 35, Number 4, pp. 519-530.

Hayek, F.A. 1948 [1996]. Individualism and Economic Order. Chicago, IL: The University of Chicago Press.

Hayek, F.A. 1952. The Sensory Order. London: Routledge and Kegan Paul.

Hayek, F.A. 1988. The Fatal Conceit. London: Routledge.

Heilbroner, R.L. 1990. “After Communism.” The New Yorker. 10 September 1990, pp. 91-100.

Higgs, R. 1987. Crisis and Leviathan: Critical Episodes in the Growth of American Government. New York: Oxford University Press.

Higgs, R. 1992. "Wartime Prosperity? A Reassessment of the U.S. Economy in the 1940s.” The Journal of Economic History. Vol. 52, No. 1, pp. 41-60.

Hülsmann, J.G. 2007. Mises: The Last Knight of Liberalism. Auburn, AL: Ludwig von Mises Institute.

Kjar, S.A. and W.L. Anderson. 2009. "War and the Austrian School: Applying the Economics of the Founders.” The Economics of Peace and Security Journal. Vol. 5, No. 1, pp. 6-11.

Mises, L. 1944a. Omnipotent Government: The Rise of the Total State and Total War. New Haven, CT: Yale University Press.

Mises, L. 1944b. Bureaucracy. New Haven, CT: Yale University Press.

Mises, L. 1949. Human Action. New Haven, CT: Yale University Press

Mises, L. 1922 [1981]. Socialism: An Economic and Sociological Analysis. Indianapolis, IN: Liberty Press $\backslash$ Liberty Classics.

Mises, L. 1919 [1983]. Nation, Staat und Wirtschaft. Vienna: Manz. Translated by L.B. Yeager, Nation, State, and Economy. New York: New York University Press.

Mises, L. 1912 [1934, 1980]. The Theory of Money and Credit. London: Jonathan. Reprinted Indianapolis, IN: Liberty Classics.

Nobel Prize Committee. 1974. "The Sveriges Riksbank Prize in Economic Sciences in Memory of Alfred Nobel 1974.” http://nobelprize.org/nobel_prizes/economics/ laureates/1974/ [accessed 22 November 2010].

Porter, B. 1994. War and the Rise of the State. New York: The Free Press.

Robbins, L. 1947. The Economic Problem in Peace and War. London: Macmillan. Southerland, D.E. 1998. The Emergence of Total War. Abilene, TX: The McWhiney Foundation Press. 